\title{
The Folklore of Man-Eating Plants
}

\author{
JOSEPH VILLARI •Ashburn, Virginia •USA・joeyvillari@yahoo.com
}

Keywords: history: legends.

Stories and tales of man-eaters seep from every continent on earth. They instantly conjure up feelings of fascination, adventure, and terror. Too frequently these events are over-sensationalized and told with a journalistic (shall we say "attention-grabbing") slant. The stories usually portray the accused man-eater as some horrible beast, and the men being eaten as innocent, helpless victims. This is mostly far from the truth; most occurrences of predation on people are caused or instigated by the people who are attacked. In fact most animals labeled with the unfortunate moniker of man-eater are quite innocent of that accusation. But, what if this accused man-eater is a plant!

There are over 660 known species and subspecies of carnivorous plants (Rice 2007). Needless to say, none are known man-eaters. Common knowledge dictates that the main diet of carnivorous plants (at least the species so far discovered) is insects. So should carnivorous plants really be called insectivorous plants? Over time, observations by scientists have proven otherwise. There are cases of carnivorous plants capturing and devouring frogs, lizards, and even small mammals such as mice or small rats. (There are also mentions of birds becoming prey, but I cannot find any specific observations of that.) Most carnivorous plant growers certainly know their plants can digest small chunks of meat placed within the traps. But it gets more interesting because there are anecdotes that support the idea that some species of carnivorous plants are "moving up the ranks," so to speak. In his 1998 book The Savage Garden, Peter D'Amato recounts a story told to him by a "well-to-do" couple who recently returned from a botanical garden in Malaysia where they witnessed massive pitcher plants hanging from trees. While peering through a fence waiting for the exhibit to open, they observed an attendant pulling baby monkeys out of the giant pitchers. While they stated most scampered off unharmed, some monkeys appeared not so lucky and were put into a pail. The husband continues on to say that they caught up with the attendant and questioned him about what he was doing, and the attendant stated that the dead monkeys in the pitcher plants needed removal because they were upsetting to the tourists. D'Amato suspects the couple misidentified the species of mammal being pulled from the traps; his opinion is that the unfortunate victims to be of the mice family, not the simian, but he could not document or follow up on the story. The natural world has such wonders that it might be entirely plausible for very small monkeys to succumb to such a plant. But plants claimed to consume prey the size of a man certainly might invoke a different attitude.

The western world first got wind of stories describing plants or trees of the man-eating variety when an article was published in 1878; it recited a letter written by German traveler Carle Liche who was exploring Madagascar. In this letter Liche wrote of a man-eating tree and a primitive tribe of pygmy people called the Mkodos. The story, summed up, describes the tribe of Mkodos ritually sacrificing a girl to the tree (Mackal 1980). Liche describes the appearance of the man-eating plant as a:

"pineapple eight feet high and thick in proportion resting upon its base and denuded of leaves". He goes on to say the trunk "was not the color of an [b]anana, but a dark dingy brown, and apparently as hard as iron. From the apex of this truncated cone (at least two feet in diameter) eight leaves hung sheer to the ground, like doors swung back on their hinges. These leaves that were joined at the top of the tree at regular intervals were about eleven or twelve feet long, and shaped very much like the leaves of the American agave or century plant. They were two feet through at their thickest point and three feet wide, tapering to a sharp point that looked like a cow's horn, very convex on the outer (but 
now under) surface, and on the under (now upper) surface slightly concave. This concave face was thickly set with strong thorny hooks like those on the head of the teazle. These leaves hanging thus limp and lifeless, dead green in color, had in appearance the massive strength of oak fibre. The apex of the cone was a round white concave figure like a smaller plate set within a larger one. This was not a flower but a receptacle, and there exuded into it a clear treacly liquid, honey sweet, and possessed of violent intoxicating and soporific properties. From underneath the rim (so to speak) of the undermost plate a series of long hairy green tendrils stretched out in every direction towards the horizon. These were seven or eight feet long, and tapered from four inches to a half inch in diameter, yet they stretched out stiffly as iron rods. Above these (from between the upper and under cup) six white almost transparent palpi reared themselves toward the sky, twirling and twisting with a marvelous incessant motion, yet constantly reaching upwards. Thin as reeds and frail as quills, apparently they were yet five or six feet tall, and were so constantly and vigorously in motion, with such a subtle, sinuous, silent throbbing against the air, that they made me shudder in spite of myself, with their suggestion of serpents flayed, yet dancing upon their tails."

Later this story and its details were investigated by many including Dr. Roy Mackal and Willy Ley. Neither Ley nor Mackal, who investigated this matter independently and years apart, found any evidence to support the story. They could not even find any support of a tribe of people comparable to the primitive pygmy Mkodos living in Madagascar, or even the existence of a German traveler by the name of Carle Liche (Mackal 1980). Mackal, a zoologist at the University of Chicago, also made note of the improbability that a plant could sustain so much frantic and constant palpi motion as described in Liche's story. But, the man-eating tree of Madagascar story does not end with Liche.

A world explorer named Chase Salmon Osborn, LL.D., who also served as the governor of Michigan from 1911 to 1913, heard of the horrible tree residing in Madagascar and went there to try his luck at finding the tree. Upon his return he authored a book of his adventure aptly named Madagascar, Land of the Man-Eating Tree (see http://www.madagascar-library.com/r/1090.html), published in 1924. Osborne never did see the fabled tree. But during his exploration of the island he did hear stories and myths about it from all the native people he encountered of many different tribes. He even questioned local missionaries about the existence of the tree; most were skeptical of the tree, but not all (Mackal 1980). Even though Osborn returned empty-handed, he still believed there was something to this mystery and was impressed by the information he recovered during his travels. In defense of his opinion of the possible existence of a man-eating tree he pointed out that Madagascar has been known as "The Land of the Man-Eating Tree" since its discovery and that most of this island at the time remained largely unexplored. He admitted that the only thing improbable about the tree was its size, which he observed, "is not always a safe measuring standard of values". He also describes a similar unknown plant, but of a smaller size, which he saw in London (Michell \& Rickard 2000). He writes, "At the London Horticultural Hall in England there is a plant that eats large insects and mice. Its principal prey are the latter. The mouse is attracted to it by a pungent odor that emanates from the blossom which encloses a perfect hole just big enough for the mouse to crawl into. After the mouse is in the trap bristle-like antennae enfold it. Its struggles appear to render the Gorgonish things more active. Soon the mouse is dead. Then digestive fluids much like those of animal stomachs exude and the mouse is macerated, liquefied and appropriated. This extraordinary carnivorous plant is a native of tropical India. It has not been classified as belonging to any known botanical species." This no doubt is the closest we have come to an unknown and fantastic plant that sounds like it could easily be a new species. It does not seem to be unlike the genus Nepenthes and yet has some original, more active trapping methods and seems to prey regularly on larger prey, such as mice.

Shortly after the publication of Liche's report, botanists tried to close the book on the possibility of the man-eating tree of Madagascar. But at least one prominent botanist seemed to consider its existence; when Francis Ernest Lloyd noted in his book The Carnivorous Plants (1942), after 
talking of his list of all known species of carnivorous plants and other plants thought to be carnivorous but were later proven not to be, he notes "The 'man-eating tree of Madagascar' must at present also be excluded, since the evidence of its existence is elusive". But today it would seem safe to say the Man-eating tree of Madagascar must stay in the realm of folklore, and for now, not be seen in the index of Madagascar's botanical field guides (though one can hope for further searches to change this!).

But evidence for large-vertebrate-eating trees does not end there...

In Buel's 1887 book Land and Sea, he talked of an account given to him by a "gentleman of his acquaintance, who, for a long time, resided in Central America" describing a tree named a Yate-veo ("I can see you") which is said to grow in areas in Central and South America with similar species residing in Africa and on the shores of the Indian Ocean (in: Michell \& Rickard 2000):

Travelers have told us of a plant, which they assert grows in Central Africa and also in South America, that is not contented with the myriad of larger insects which it catches and consumes, but its voracity extends to making even humans its prey. This marvelous vegetable Minotaur is represented as having a short, thick trunk, from the top of which radiate giant spines, narrow and flexible, but of extraordinary tenaciousness, the edges of which are armed with barbs, or dagger-like teeth. Instead of growing upright, or at an inclined angle from the trunk, these spines lay their outer ends upon the ground, and so gracefully are they distributed that the trunk resembles an easy couch with green drapery around it. The unfortunate traveler, ignorant of the monstrous creation which lies in the way, and curious to examine the strange plant, or to rest himself upon its inviting stalk approaches with out a suspicion of his certain doom. The moment his feet are set within the circle of the horrid spines, they rise up, like gigantic serpents, and entwine themselves about him until he is drawn upon the stump, when they speedily drive their daggers into his body and thus complete the massacre. The body is crushed until every drop of blood is squeezed out of it and becomes absorbed by the gore-loving plant, when the dry carcass is thrown out and the horrid trap set again.

Later, a Dr. Andrew Wilson wrote a column titled "Science Jottings" in an August 27, 1892, issue of Illustrated London News, in which he wrote of a naturalist by the name of Mr. Dunstan who was "botanizing" in one of the many swamps surrounding Nicaragua Lake. While hunting for specimens he suddenly heard his dog cry out in pain. Running towards the animal's cry, "Mr. Dunstan found him enveloped in a perfect network of what seemed to be a fine, ropelike tissue of roots and fibres. The plant or vine seemed composed entirely of bare-interlacing stems, resembling more than anything else the branches of a weeping willow denuded of its foliage, but of a dark, nearly black hue, and covered with a thick, viscid gum that exuded from the pores." (Mackal 1980). Dunstan eventually, and with great effort, cut the dog free. He stated the dog's skin "appeared to be actually sucked or puckered in spots" and reported the skin on his hand while freeing his dog got "red and blistered" from the plant grabbing him. Finally, he told that the tree is well known to the natives, and they tell many tales of its "death-dealing powers." In a following article contained in a September 24, 1892, issue, Dr. Wilson wrote:

The 'snake-tree' is described in a newspaper paragraph as found on an outlying spur of the Sierra Madre, in Mexico. It has movable branches (by which I suppose, is meant sensitive branches), of a 'slimy, snaky appearance,' which seized a bird that incautiously alighted on them, the bird being drawn down till the traveler lost sight of it. Where did the bird go to? Latterly it fell to the ground, flattened out, the earth being covered with bones and feathers, the debris, no doubt, of former captures. The adventurous traveler touched one of the branches of the tree. It closed upon his hand with such force as to tear the skin when he wrenched it away. He then fed the tree with chickens, and the tree absorbed their blood by the means of the suckers (like those of the octopus) with which its branches were covered.

Those two accounts sound eerily familiar to one another even though the prey differed in size. But there is more to come of a plant of this description. 
In an August 1934 edition of Wide World Magazine, a French explorer, Baron Byron Khun de Prorok, recounted some memories of his journeys leading a party of explorers into the impenetrable jungle regions of Chiapas in southern Mexico (Shuker 2003). One of these memories he recounts thusly:

After two hours' march we breathed with difficulty, and were bathed in perspiration.

Suddenly I saw Domingo, the leader of the guides, standing before an enormous plant and making gestures for me to go to him. I wondered what could be the matter. I soon saw; the plant had just captured a bird! The poor creature had alighted on one of the leaves, which had promptly closed, its thorns penetrating the body of the little victim, which endeavored vainly to escape, screaming meanwhile in agony and terror. "Plante vampire!" explained Domingo, a cruel smile spreading over his face. Involuntarily I shuddered; the forest was casting its evil spell upon me.

Shuker points out that De Prorok was a renowned explorer, that the last three accounts of unknown carnivorous plants above are remarkably similar in morphology, and that if in fact the stories are true, they are possibly of the same species. The discrepancies, which are so minute, certainly can be explained by error in reporting. Shuker's opinion is that De Prorok's description is probably the most accurate. He defends this position, saying it would be much more simple to accept the existence of a plant that has sensitive thorn-bearing leaves, similar to a trapping mechanism already in use by the Venus Flytrap, than a plant evolving botanical sucker-like devices that are capable of actively draining a bird of its blood.

There is also one last report coming from South America, specifically Brazil. It involves a report from Randall Schwartz's 1974 book, Carnivorous Plants. He claims that in a "recent report" by a Brazilian explorer venturing through the rainforest searching for a settlement of Yatapu Indians, he found a tree capable of consuming animals. He said it released a distinctive scent that attracted monkeys, urging them to come towards and climb the tree's trunk. While climbing the trunk of the tree the leaves would suddenly wrap around them, rendering them helpless and proceeding to digest them (Shuker 2003). This monkey-eating behavior might remind you of the account told to D'Amato by the "well to do" couple, with one difference being this Brazilian account deals with an apparently unknown species of carnivorous plant, given away by its different trapping mechanism. It is interesting to note the genus Nepenthes has been referred to by the nickname "monkey cups" by some, due to some reports of monkeys occasionally drinking water from the plant's pitchers. The previous reports of the monkeys becoming prey certainly give a deadly spin on that epithet.

Lastly, there are many recent reports coming from India of a cow-eating tree. As recently as October 23, 2007, a report came from the village of Padrame bordering the Uppinangady range forest (Anonymous 2007). Residents spotted a carnivorous tree trying to capture a cow. Reports state the cow was left to graze in the forest by the owner, Anand Gowda, when the cow was suddenly grabbed by the tree's branches and "pulled from the ground." A terrified cowherd witnessing this ran to the village and got Gowda and a group of villagers to hurry to the tree. The news report then states:

Before the tree could have its meal, Anand Gowda and the villagers struck mortal blows to the branches that turned limp and the cow was rescued. Uppinangady range forest officer (RFO) Subramanya Rao said the tree was described as 'pili mara' (tiger tree) in native lingo. He had received many complaints about cattle returning home in the evenings without tails. On Friday, the field staff confirmed coming across a similar tree in Padrane, partially felled down. However no detailed inquiry was made as the authorities were not asked for any report, Rao said.

The possibility of a cow-eating tree does seem less than promising considering a cow's size. But maybe there is some tiny grain of truth hidden behind the villager's folklore and superstition. Maybe the cow-eating tree's description and legend is based on a smaller, yet similar plant that devours small animals and gives rise to ideas that a plant could consume bovines.

To conclude this article, it must be said that a plant or a tree would certainly not evolve to prey strictly on man. (If so we would probably be aware of it before now.) Based on these stories 
you could speculate that possibly somewhere in the dark, unexplored rainforests there could be a plant that has the ability to prey on animals the size of man, and if given the opportunity would devour a human being. Yet all these stories could also be explained away as tales and yarns. But maybe one day, we will find out that prehistorically man-eating plants did exist, and the reports received today could be explained by vestiges in our memory of the day when man had reason to fear plants that possessed these gruesome abilities.

\section{References}

Anonymous. 2007. Cow-eating trees of Padrame.

http://www.newindpress.com/NewsItems.asp?ID=IEK20071023040252\&Page=K\&Headline=

'Cow-eating'+trees+of+Padrame\&Title=Southern+News+-+Karnataka\&Topic=0. Accessed 23 October 2007.

D'Amato, P. 1998. The Savage Garden. Ten Speed Press, Berkeley, California.

Lloyd, F.E. 1942. The Carnivorous Plants. Chronica Botanica, New York, New York.

Mackal, R. 1980. Searching for Hidden Animals: An Inquiry into Zoological Mysteries.

Doubleday, New York, New York.

Michell, J., and Rickard, B. 2000. Unexplained Phenomena. Penguin Group, London.

Osborn, C.S. 1924. Madagascar, Land of the Man-Eating Tree. New York Republic Publishing Company, New York.

Rice, B. 2007. Carnivorous plant FAQ v11.5, http://www.sarracenia.com/faq.html. Accessed March 2008.

Schwartz, R. 1974. Carnivorous Plants. Praeger Publishers, New York.

Shuker, K. 2003. The Beasts that Hide from Man. Paraview Press, New York, New York.

\section{BOARD MEMBER ELECTION}

The ICPS Board has a vacancy. All members of the ICPS are encouraged to run for a board position in the ICPS. If you would like to participate in the workings of the ICPS, please email a 250-word election statement to Richard Myers, richard@carnivorousplants.org. Your election statements must be received by 1 August 2009. In your statement, you may wish to note your experience, why you want to run for office, and what you wish to accomplish. Your statements will be printed in the September issue.

The ICPS is a growing, active organization. In order to participate as a board member, email access is essential. Furthermore, board members are expected to work hard! So while we welcome and encourage your interest as a board member, remember that it is more than a vanity post! Consider running for office-your energy is appreciated and needed!

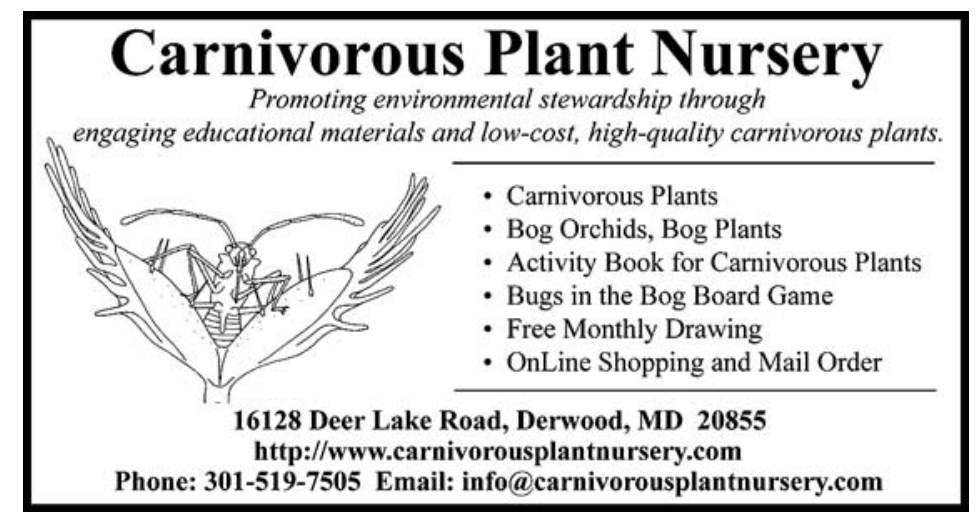

